\title{
Comparison of the safety and clinical efficacy of glucagon- like peptide-1 receptor agonist and $\alpha$-glucosidase inhibitor among Chinese people with type 2 diabetes
}

\author{
Qinjin $\mathrm{Hu}^{1}$, Jingjing $\mathrm{Zhu}^{2 *}$ \\ ${ }^{1}$ Department of Endocrinology and Nephrology, Chongqing The Seventh People's Hospital, Chongqing 400054, ${ }^{2}$ Department of \\ Endocrinology, Ningbo No. 6 Hospital, Ningbo, Zhejiang 315040, China
}

*For correspondence: Email: zhujingjing189@hotmail.com; Tel/Fax: 0086-0574-87996203

Sent for review: 7 December 2020

Revised accepted: 29 April 2021

\begin{abstract}
Purpose: To compare the safety and efficacy of once-weekly prescription of GLP-1 receptor agonists (adlyxin) with those of $\alpha$-glucosidase inhibitor (voglibose) and other reference drugs (RD).

Methods: A total of 1250 stable diabetes-mellitus patients from the Department of Endocrinology, Ningbo No. 6 Hospital, Ningbo, Zhejiang 315040, China were enrolled in this study between Feb 2018 and Jan 2020. They were treated using physical exercise and diet chart therapy. The patients were assigned to three different groups and administered GLP-1 receptor agonist (GLP-1RA) or glucosidase inhibitor (voglibose) and other reference drugs (RDs). The safety and efficacy of these drugs were compared. The primary endpoint was the number of treatment-emergent adverse events (TEAEs), while the secondary endpoints were based on symptomatic hypoglycaemic episodes and other biochemical parameters.

Results: Patients who used a-glucosidase inhibitors had the highest percentage of TEAEs, when compared to those on GLP-1RAs and RDs $(p<0.05)$. No specific cases of severe hypoglycaemia were observed among all the groups. Users of adlyxin also achieved significant glycaemic control at the end of the study period, when compared to voglibose users, with a mean HbA1c baseline of $8.2 \%$ ( $p<$ 0.05).

Conclusion: These results indicate that the GLP-1 receptor agonist adlyxin achieved good glycaemic control. Thus, it has beneficial potential for use among type 2 diabetes in the Chinese population.
\end{abstract}

Keywords: Adlyxin, GLP-1 receptor agonist, Type 2 diabetes, Glycaemic control, a-Glucosidase inhibitors

\begin{abstract}
This is an Open Access article that uses a funding model which does not charge readers or their institutions for access and distributed under the terms of the Creative Commons Attribution License (http://creativecommons.org/licenses/by/4.0) and the Budapest Open Access Initiative (http://www.budapestopenaccessinitiative.org/read), which permit unrestricted use, distribution, and reproduction in any medium, provided the original work is properly credited.
\end{abstract}

Tropical Journal of Pharmaceutical Research is indexed by Science Citation Index (SciSearch), Scopus, International Pharmaceutical Abstract, Chemical Abstracts, Embase, Index Copernicus, EBSCO, African Index Medicus, JournalSeek, Journal Citation Reports/Science Edition, Directory of Open Access Journals (DOAJ), African Journal Online, Bioline International, Open-J-Gate and Pharmacy Abstracts

\section{INTRODUCTION}

The sharp increase in the number of type 2 diabetes (T2D) patients globally may be due to obesity and physical inactivity [1]. There is also an increase in the number of T2D patients among the Asian population, mostly in China [2]. In the Chinese population, the sudden increase in T2D population may be because of better economic development, population growth, aging, and Westernized lifestyle [3]. 
Diabetes mellitus or T2D is a progressive metabolic disease which is characterized by hyperglycemia and insulin deficiency [4]. The complications caused by T2D have become such a global health issue that there is urgent need for the prevention and management of the disease [5]. In spite of various antidiabetic drug classes that have been approved for T2D patients, the ultimate therapeutic goals for T2D are yet to be fully achieved. Thus, there is need for the development of a novel therapeutic approach that will be more efficient than the existing ones. Several drug classes for good glycaemic control and effective long- term use are already available in the market. However, the problem of excess mortality and morbidity still remain serious medical concerns $[6,7]$. When the onset of T2D is mostly influenced by obesity and lack of physical activity, glycaemic control drugs are generally recommended.

The commonly used therapies for glycaemic control are glucagon-like peptide 1 (GLP-1) agonists, $\alpha$-glucosidase inhibitor, dipeptidyl peptidase 4 (DPP-4), and sodium/glucose cotransporter 2 (SGLT-2) inhibitors [8]. However, the various classes of drugs are ineffective in achieving the recommended glycaemic level, which is still a challenge for many patients. Hence, it is very important to customize each treatment based on control of weight gain and achievement of glycaemic targets. In fact, glucagon-like peptide-1 receptor agonists (GLP1RAs) are known for achieving glycaemic control by reducing body weight, relative to other T2D therapies [9]. Moreover, there are several studies on comparative clinical and cost-effective analysis on DPP4 and SGLT inhibitors. However, not much is known on comparative clinical efficacy of glucagon-like peptide 1 (GLP-1) agonists and $\alpha$-glucosidase inhibitors, and their optimal treatments [10-12]. Therefore, the present study was aimed at comparing the safety and efficacy of once-weekly prescription of GLP1 receptor agonists (adlyxin) with those of $\alpha-$ glucosidase inhibitor (voglibose) monotherapy $(1.0 \mathrm{mg})$ and other reference drugs.

\section{EXPERIMENTAL}

\section{Ethical statement and approval}

All procedures were carried out in accordance with the Declaration of Helsinki 1964 and its later amendments [13]. Written informed consent was provided by all patients and participants. Consent was obtained from each subject regarding their personal information on demographic factors, and any other history of medical condition using a questionnaire. All protocols and procedures were approved by the institutional Medical Ethical Research Committee (approval no. $\mathrm{NH} /$ End/34613-43C).

\section{Study population}

A total of 1250 stable diabetes mellitus patients at the Ningbo No.6 Hospital, Ningbo, Zhejiang, China, 315040 between February 2018 and January 2020 who were treated with physical exercise, diet chart therapy and prescription of GLP-1 receptor agonists (adlyxin) or glucosidase inhibitor (voglibose) and other reference drugs, were investigated. The study population comprised patients in the age group of $40-70$ years, with $\mathrm{HbA} 1 \mathrm{c}$ levels between 50 and 90 $\mathrm{mmol} / \mathrm{mol}$ during the screening period. Patients who developed chronic diseases such as renal impairment, vascular diabetes and pancreatitis were excluded from the study.

\section{Grouping and treatment}

The participants were assigned to three different groups treated with GLP-1 receptor agonists or a-glucosidase inhibitor or RD. Initially, all the groups were subjected to a mandatory 10-week diet and exercise therapy. Group 1 received 1.0 $\mathrm{mg}$ of $\alpha$-glucosidase inhibitor (voglibose), while group 2 was given $1.0 \mathrm{mg}$ of GLP-1 receptor agonist (adlyxin). The third group received 1.0 $\mathrm{mg}$ of RD such as insulin or acarbose, once a week for 24 months. Follow-up continued till the end of the study. The drugs were administered once weekly via subcutaneous injection in the thigh, abdomen, or upper arm, on the same day of the week.

\section{Endpoint/outcome indicators}

The main outcome of the study was comparison of the safety and efficacy of GLP-1 receptor agonists (adlyxin) with those of $\alpha$-glucosidase inhibitor (voglibose) among Chinese people with T2D. The primary endpoint was the number of treatment-emergent adverse events (TEAEs) during 24 months of treatment, while the secondary endpoint was the severity of blood glucose level confirmed by symptomatic hypoglycaemia episodes. These included changes from the baseline values and safety parameters from hematology, biochemistry, calcitonin and pulse rate variables.

\section{Statistical analysis}

Statistical analysis was carried out using SPSS 21.0 software. All values are expressed as mean \pm standard deviation (mean \pm SD). One-way analysis of variance (ANOVA) was used for 
multiple comparisons, while Student's $t$-test was performed for comparison between two groups. Values of $p<0.05$ were considered statistically significant.

\section{RESULTS}

A total of 1250 participants were investigated and given GLP-1 receptor agonist adlyxin $(n=500)$, $\alpha$ glucosidase inhibitor voglibose $(n=500)$ or RDs (insulin or acarbose). In the group treated with GLP-1 receptor agonist, there were 25 aborted treatments involving participants who discontinued from the investigation, while $48 \alpha$ glucosidase inhibitor users and 18 RD users discontinued during the study period. Adverse events were responsible for the discontinuation. However, baseline characteristics were comparable amongst the three groups (Table 1).

The incidence of TEAEs was highest among the a-glucosidase inhibitor group (87.37\%), followed by GLP-1 receptor agonist group (86.15\%), and least in RD group (70.69\%). These results are shown in Table 2. The GLP-1 receptor agonist users experienced $6.06 \%$ serious adverse events (SAEs) during the secondary safety endpoint. In contrast, users of a-glucosidase inhibitor and and RDs experienced higher SAEs of 8.21 and $7.33 \%$ respectively. There were no fatalities during the study period. In terms of severity, the AEs were mostly mild-to-moderate in many cases. In the case of voglibose users, $5.26 \%$ of the participants discontinued treatment due to AEs, while $8.23 \%$ of adlyxin users discontinued due to AEs (Table 2).

In most cases, gastrointestinal problems were the main reason for the discontinuation of treatment. Diabetic retinopathy was observed among $7.58 \%$ of voglibose users, $5.68 \%$ of adlyxin users, and $6.47 \%$ of RD users (Table 3 ). There were no specific cases of severe hypoglycemia among all groups. Neoplasms were reported in $7.14,5.47$, and $6.9 \%$ of the patients treated with voglibose, adlyxin, and RD, respectively (Table 3 ).

In the voglibose treatment group, benign and colorectal cases were most common (8.66 and $4.11 \%$, respectively), when compared to 3.58 and $2.53 \%$, respectively, in adlyxin users. With respect to glycaemic control at the end of the study period (24 months), the mean $\mathrm{HbA} 1 \mathrm{c}$ (baseline $8.2 \%$ ) was significantly reduced in adlyxin (GLP-1 receptor) group, when compared to voglibose ( $\alpha$-glucosidase inhibitor) group. Most of the adlyxin (GLP-1 RA) users were able to achieve the $\mathrm{HbA} 1 \mathrm{c}$ target of $<7.0 \%$. Mean body weight was also significantly decreased in participants treated with adlyxin, when compared to voglibose and reference drug users. Moreover, there were significant reductions in blood pressure among users of adlyxin, when compared to baseline levels. These results are shown on Table 4.

\section{DISCUSSION}

In this study, users of adlyxin were able to tolerate overall without any further safety labels. In the primary endpoint, adlyxin users had higher TEAEs than those who used voglibose ( $\alpha$ glucosidase inhibitor) and RDs. However, the occurrence of SAEs was distributed uniformly in the groups. Gastrointestinal adverse events (AEs) were dominant among the GLP-1RAs users, but the symptoms were moderate and mild in many cases, and gradually subsided over time. The AEs also accounted for most of the treatment discontinuations. In fact, gastrointestinal disorders have been reported as common side effects among GLP-1RA users $[14,15]$.

Table 1: Baseline characteristics of the investigated population

\begin{tabular}{|c|c|c|c|c|c|c|}
\hline \multirow[t]{2}{*}{ Variable } & \multicolumn{2}{|c|}{$\begin{array}{c}\text { a-Glucosidase inhibitor } \\
\text { Voglibose } \\
n=475\end{array}$} & \multicolumn{2}{|c|}{$\begin{array}{l}\text { iLP-1 receptor agonists } \\
\text { Adlyxin } \\
n=462\end{array}$} & \multicolumn{2}{|c|}{$\begin{array}{l}\text { Reference drug } \\
\text { Insulin, acarbose, etc } \\
n=232\end{array}$} \\
\hline & Mean & $S D$ & Mean & $S D$ & & \\
\hline Age & 62.4 & $(9.3)$ & 61.8 & $(9.5)$ & 63.1 & $(9.6)$ \\
\hline Male/ female (\%) & $68.5 / 31.5$ & & $71.5 / 28.5$ & & $70.8 / 29.2$ & \\
\hline $\mathrm{HbA} 1 \mathrm{c},(\mathrm{mmol} / \mathrm{mol})$ & 66.3 & $(10.2)$ & 65.3 & $(9.8)$ & 65.6 & (10.4) \\
\hline $\mathrm{HbA} 1 \mathrm{c}<\%$ & 8.2 & $(1.2)$ & 8.1 & $(0.9)$ & 8.3 & $(1.3)$ \\
\hline $\mathrm{FPG}(\mathrm{mmol} / \mathrm{L})$ & 9.0 & $(1.7)$ & 8.8 & $(1.8)$ & 8.9 & (1.8) \\
\hline $\mathrm{FPG}(\mathrm{mg} / \mathrm{dL})$ & 162.7 & (29.3) & 161.8 & (28.1) & 162.4 & (29.9) \\
\hline Body weight (kg) & 71.6 & (12.4) & 68.6 & (11.4) & 72.3 & (12.8) \\
\hline BMI $\left(\mathrm{kg} / \mathrm{m}^{2}\right)$ & 26.5 & $(4.3)$ & 26.3 & $(4.1)$ & 26.8 & $(4.7)$ \\
\hline eGFR $\left(\mathrm{mL} / \mathrm{min} / 1.73 \mathrm{~m}^{2}\right)$ & 102.5 & (19.1) & 101.2 & (18.3) & 103.4 & (20.3) \\
\hline Physical therapy & 159 & (25.3) & 175 & (24.1) & 82 & (18.7) \\
\hline
\end{tabular}


Table 2: Incidence of various adverse events observed in the treatment groups

\begin{tabular}{|c|c|c|c|c|c|c|c|c|c|c|c|c|}
\hline \multirow{2}{*}{$\begin{array}{l}\text { Variable } \\
\text { Overview of treatment } \\
\text { emergent AEs }\end{array}$} & \multirow[b]{2}{*}{$\mathrm{n}^{*}$} & \multicolumn{2}{|c|}{ Voglibose } & \multicolumn{6}{|c|}{ Adlyxin } & \multicolumn{3}{|c|}{ Reference drugs } \\
\hline & & $(\%)$ & $\mathrm{E}^{*}$ & $\mathrm{R}^{*}$ & $\mathrm{n}$ & $(\%)$ & $E$ & $\mathrm{R}$ & $\mathrm{n}$ & $(\%)$ & $E$ & $\mathrm{R}$ \\
\hline Number of participants & 475 & & & & 462 & & & & 232 & & & \\
\hline AEs (total) & 415 & 87.37 & 921 & 341.4 & 418 & 90.48 & 892 & 312.4 & 164 & 70.69 & 587 & 383.5 \\
\hline Death & 0 & 0 & 0 & 0 & 0 & & & & 0 & & 0 & 0 \\
\hline Serious & 39 & 8.21 & 28 & 11.3 & 28 & 6.06 & 17 & 6.2 & 17 & 7.33 & 17 & 8.5 \\
\hline Severity Severe & 23 & 4.84 & 16 & 5.1 & 8 & 1.73 & 5 & 1.6 & 7 & 3.02 & 3 & 1.7 \\
\hline Moderate & 63 & 13.26 & 51 & 22.8 & 62 & 13.42 & 41 & 16.4 & 31 & 13.36 & 26 & 18.3 \\
\hline Mild & 412 & 86.74 & 945 & 325.6 & 424 & 91.77 & 842 & 289 & 174 & 75 & 352 & 196 \\
\hline $\begin{array}{l}\text { Leading to premature } \\
\text { treatment discontinuation }\end{array}$ & 25 & 5.26 & 18 & 6.2 & 38 & 8.23 & 23 & 12.5 & 18 & 7.76 & 11 & 5.1 \\
\hline $\begin{array}{ll}\text { Infections } & \text { and } \\
\text { infestations } & \end{array}$ & 265 & 55.79 & 243 & 87.4 & 219 & 47.4 & 178 & 69.4 & 124 & 53.45 & 175 & 75.2 \\
\hline Pharyngitis & 27 & 5.68 & 17 & 4.8 & 21 & 4.55 & 12 & 3.8 & 6 & 2.59 & 8 & 3.4 \\
\hline Nasopharyngitis & 158 & 27.48 & 128 & 46.1 & 148 & 32.03 & 98 & 31.4 & 83 & 35.78 & 76 & 43.3 \\
\hline Gastrointestinal disorders & 272 & 57.26 & 274 & 89.5 & 267 & 57.79 & 284 & 90.2 & 54 & 23.28 & 53 & 32.7 \\
\hline Gastroenteritis & 31 & 6.53 & 21 & 6.7 & 14 & 3.03 & 11 & 3.1 & 5 & 2.16 & 9 & 2.7 \\
\hline Nausea & 59 & 12.42 & 43 & 17 & 98 & 21.21 & 54 & 21.6 & 5 & 2.16 & 9 & 1.3 \\
\hline Constipation & 89 & 18.74 & 49 & 21.6 & 79 & 17.1 & 38 & 13.7 & 12 & 5.17 & 14 & 4.3 \\
\hline Abdominal discomfort & 32 & 6.74 & 19 & 6.1 & 35 & 7.58 & 16 & 6.5 & 17 & 7.33 & - & - \\
\hline Diarrhoea & 48 & 10.11 & 42 & 14.7 & 75 & 16.23 & 34 & 12.4 & 21 & 9.05 & 17 & 4.7 \\
\hline Vomiting & 27 & 5.68 & 22 & 5.9 & 32 & 6.93 & 15 & 4.3 & 6 & 2.59 & 6 & 1.7 \\
\hline Investigations & 83 & 17.47 & 73 & 18.5 & 119 & 25.76 & 78 & 27.7 & 22 & 9.48 & 18 & 5.2 \\
\hline Lipase increased & 43 & 9.05 & 32 & 8.7 & 68 & 14.72 & 25 & 8.7 & 8 & 3.45 & 6 & 2.1 \\
\hline Amylase increased & 16 & 3.37 & 14 & 5 & 27 & 5.84 & 9 & 4.6 & 3 & 1.29 & 1 & 1.1 \\
\hline
\end{tabular}

${ }^{*} \mathrm{n}=$ no. of participants; $\mathrm{E}=$ no. of events; and $\mathrm{R}=$ event rate

Table 3: Characteristics of adverse events based on metabolism and other disorders

\begin{tabular}{|c|c|c|c|c|c|c|c|c|c|c|c|c|}
\hline \multirow{2}{*}{$\begin{array}{l}\text { Variable } \\
\text { Overview of treatment } \\
\text { emergent AEs }\end{array}$} & \multicolumn{4}{|c|}{ Voglibose } & \multicolumn{4}{|c|}{ Adlyxin } & \multicolumn{4}{|c|}{ Reference Drugs } \\
\hline & $\mathrm{n}^{*}$ & $(\%)$ & $E^{*}$ & $\mathrm{R}^{*}$ & $\mathrm{n}$ & $(\%)$ & $E$ & $\mathrm{R}$ & $\mathrm{n}$ & $(\%)$ & $E$ & $\mathrm{R}$ \\
\hline Number of participants & 475 & & & & 462 & & & & 232 & & & \\
\hline $\begin{array}{l}\text { Metabolism and nutrition } \\
\text { disorders }\end{array}$ & 49 & 10.32 & 33 & 11.5 & 71 & 15.37 & 27 & 9.5 & 7 & 3.02 & 5 & 2.4 \\
\hline Decreased appetite & 41 & 8.63 & 27 & 9.4 & 59 & 12.77 & 31 & 11.2 & 4 & 1.72 & 2 & 0.7 \\
\hline Diabetic retinopathy & 35 & 7.58 & 16 & 5.6 & 27 & 5.68 & 14 & 4.7 & 15 & 6.47 & 9 & 3.2 \\
\hline Eye disorders & 68 & 14.32 & 52 & 19.5 & 75 & 16.23 & 39 & 16.4 & 23 & 9.91 & 16 & 4.2 \\
\hline $\begin{array}{l}\text { Musculoskeletal and } \\
\text { connective tissue } \\
\text { disorders }\end{array}$ & 67 & 14.11 & 51 & 17.6 & 87 & 18.83 & 45 & 15.8 & 51 & 21.98 & 19 & 14.1 \\
\hline Back pain & 21 & 4.42 & 15 & 4.6 & 20 & 4.33 & 13 & 3.8 & 24 & 10.34 & 18 & 7.1 \\
\hline Cardiovascular events & 3 & 0.63 & 3 & 0.8 & 3 & 0.65 & 2 & 0.5 & 4 & 1.72 & & \\
\hline $\begin{array}{l}\text { Coronary } \\
\text { revascularization }\end{array}$ & 1 & 0.21 & 0 & 0 & 1 & 0.22 & 1 & 0.3 & 2 & 0.86 & & \\
\hline Heart failure & 2 & 0.42 & 0 & 0 & 0 & & & & 1 & 0.43 & & \\
\hline Benign & 40 & 8.66 & 19 & 5.3 & 17 & 3.58 & 15 & 4.3 & 8 & 3.45 & 6 & 1.1 \\
\hline Neoplasms & 33 & 7.14 & 27 & 5.1 & 26 & 5.47 & 17 & 4.5 & 16 & 6.9 & 14 & 4.2 \\
\hline Colorectal & 19 & 4.11 & 4 & 1.6 & 12 & 2.53 & 3 & 1.2 & 7 & 3.02 & & \\
\hline
\end{tabular}

Severe or BG-confirmed 112.3851 .181 .6840 .952 .1621 symptomatic; ${ }^{*} n=$ number of participants; $E=$ number of events and $R=$ magnitude of event 
Table 4: Main outcomes in the groups at the end of the study

\begin{tabular}{|c|c|c|c|c|c|c|c|}
\hline Glycaemia endpoint & & $\begin{array}{c}\alpha- \\
\text { Glucosidase }\end{array}$ & Inhibitor ( & Voglibose) & GLP-1 & $\begin{array}{l}\text { rreceptor } \\
\text { (Adlyxin }\end{array}$ & ) \\
\hline Mean [SD] & & $\begin{array}{l}\text { Difference } \\
\text { from baseline }\end{array}$ & $\begin{array}{c}\text { ETD }[95 \% \\
\text { CI] }] \\
\end{array}$ & $P$ & $\begin{array}{c}\text { )ifference from } \\
\text { baseline }\end{array}$ & $\begin{array}{c}\text { ETD }[95 \% \\
\text { Cl]b }\end{array}$ & P-value \\
\hline Glycaemia endpoint & & & -10.68 & & & -16.87 & \\
\hline $\mathrm{HbA} 1 \mathrm{c}, \mathrm{mmol} / \mathrm{mol}$ & $65.7[9.8]$ & $-16.5[0.7]$ & $\begin{array}{c}{[-11.41} \\
-9.12]\end{array}$ & $<.0001$ & $-23.1[0.6]$ & $\begin{array}{l}{[-18.12} \\
-14.14]\end{array}$ & $<.0001$ \\
\hline $\mathrm{HbA} 1 \mathrm{c},(\%)$ & $\begin{array}{c}8.2 \\
{[0.9]}\end{array}$ & $-1.4[<0.1]$ & $24[-1.15 ;-1.23]$ & $<.0001$ & $-3.5[<0.1]$ & $76[-1.61 ;-1.16]$ & $<.0001$ \\
\hline FPG, (mmol/L) & $\begin{array}{c}8.9 \\
{[1.8]}\end{array}$ & $-2.6[0.33]$ & $13[-1.82 ;-1.15]$ & $<.0001$ & $-3.8[0.1]$ & $14[-2.61 ;-2.81]$ & $<.0001$ \\
\hline FPG, (mg/dL) & $\begin{array}{l}162.3 \\
{[28.1]}\end{array}$ & $-42.3[1.5]$ & $\begin{array}{l}-29.91 \\
{[-35.02} \\
-24.79]\end{array}$ & $<.0001$ & $-49.0[1.5]$ & $\begin{array}{c}-36.63 \\
{[-41.79} \\
31.46]\end{array}$ & $<.0001$ \\
\hline \multicolumn{8}{|l|}{$\begin{array}{l}\text { Body weight } \\
\text { endpoint }\end{array}$} \\
\hline $\begin{array}{l}\text { Body weight, } \\
\text { (kg) }\end{array}$ & $\begin{array}{c}70.8 \\
{[11.4]}\end{array}$ & $-1.6[0.4]$ & $96[-2.51 ;-1.23]$ & $<.0001$ & $-3.6[0.7]$ & $82[-3.12 ;-2.12]$ & $<.0001$ \\
\hline $\mathrm{BMI}\left(\mathrm{kg} / \mathrm{m}^{2}\right)$ & $26.5[4.1]$ & $-0.9[0.4]$ & $10[-1.05 ;-0.68]$ & $<.0001$ & $-1.43[0.1]$ & $51[-1.52 ;-1.11]$ & $<.0001$ \\
\hline $\begin{array}{l}\text { Waist circumference } \\
(\mathrm{cm})\end{array}$ & $89.7[9.8]$ & $-3.1[0.6]$ & $57[-1.23 ;-1.14]$ & $<.0001$ & $-1.6[0.7]$ & $51[-2.14 ;-1.52]$ & $<.0001$ \\
\hline
\end{tabular}

There are also various studies with similar reports on treatment discontinuation arising from gastrointestinal AEs [16-18]. The safety of adlyxin (GLP-1 receptor agonists) in the cardiovascular system is of great interest. A study reported similar cardioprotective effect for the GLP-1 receptor agonist semaglutide [19]. In this study, it was observed that adlyxin (GLP1RAs) was able to achieve significant glycaemic control and BMI index when prescribed as monotherapy or in combination with other RDs. The users of adlyxin experienced a significant cardioprotective effect, when compared to users of other drugs. At the end of the treatment period, most of the participants on adlyxin (GLP1RAs) were able to achieve the target glycaemic control of the Chinese Diabetes Society target ( $\mathrm{HbA1c}<53.0 \mathrm{mmol} / \mathrm{mol}$ ) without any further weight gain and symptomatic hypoglycemia. Moreover, the efficacy of adlyxin as regards $\mathrm{HbA1c}$ level and BMI was consistent throughout the study period. Similar findings have been reported where the users of GLP-1 receptor agonists showed maintenance of clinically significant glycaemic level and BMI [20,21]. This study also demonstrated the safety profile of GLP-1 receptor agonists over $\alpha$-glucosidase inhibitor and RDs, based on their glycaemic controls and bodyweight reductions. Therefore, the use of GLP-1 receptor agonist adlyxin is justified among T2D Chinese population as a result of its potential safety profile.

\section{Limitations of the study}

The study has certain limitations. First, only a single representative drug of each class of GLP1 receptor agonists and $\alpha$-glucosidase inhibitors was considered. Secondly, the sample size was comparatively small. Thirdly, the study was based on only Chinese T2D patients. Thus, the findings may not be accurately applied to nonChinese populations.

\section{CONCLUSION}

This study reveals that the use of the GLP-1 receptor agonist adlyxin significantly reduces $\mathrm{HbA} 1 \mathrm{c}$, bodyweight and BMI, and improves the lipid profile and blood pressure of T2D patients. Adlyxin also produced good and consistent glycaemic control during the entire study period. Besides, there were no safety issues with adlyxin during the study period. Therefore, the GLP-1 receptor agonist adlyxin may be of more potential benefit to Chinese type 2 diabetes population than a-glucosidase inhibitor.

\section{DECLARATIONS}

\section{Acknowledgement}

The authors acknowledge the support received from the officials of the Ningbo No. 6 Hospital, Ningbo, Zhejiang 315040, China.

\section{Conflict of interest}

No conflict of interest is associated with this work.

\section{Contribution of authors}

We declare that this work was done by the author(s) named in this article and all liabilities 
pertaining to claims relating to the content of this article will be borne by the authors, all the authors read and approved the manuscript for publication. Qinjin Hu and Jingjing Zhu conceived and designed the study, and analysed the data, draft and wrote the manuscript.

\section{Open Access}

This is an Open Access article that uses a funding model which does not charge readers or their institutions for access and distributed under the terms of the Creative Commons Attribution License (http://creativecommons.org/licenses/by/ 4.0) and the Budapest Open Access Initiative (http://www.budapestopenaccessinitiative.org/rea d), which permit unrestricted use, distribution, and reproduction in any medium, provided the original work is properly credited.

\section{REFERENCES}

1. Bhupathiraju SN, Hu FB. Epidemiology of Obesity and Diabetes and Their Cardiovascular Complications. Circ Res 2016; 118(11): 1723-1735.

2. Yuan H, Li X, Wan G, Sun L, Zhu X, Che F, Yang Z. Type 2 diabetes epidemic in East Asia: a 35-year systematic trend analysis. Oncotarget 2017; 9(6): 6718-6727.

3. Shen X, Vaidya A, Wu S, Gao X. The Diabetes Epidemic In China: An Integrated Review Of National Surveys. EndocrPract 2016; 22(9): 1119-1129.

4. Schmidt AM. Highlighting Diabetes Mellitus: The Epidemic Continues. Arterioscler Thromb Vasc Biol 2018; 38(1): e1-e8.

5. Mota RI, Morgan SE, Bahnson EM. Diabetic vasculopathy: macro and microvascular injury. Curr Pathobiol Rep 2020; 8(1): 1-14.

6. Chaudhury A, Duvoor C, Reddy VS, Kraleti S, Chada A, Ravilla R, Marco A, Shekhawat NS, Montales MT, Kuriakose K, et al. Clinical Review of Antidiabetic Drugs: Implications for Type 2 Diabetes Mellitus Management. Front Endocrinol (Lausanne) 2017; 8: 6-14.

7. Chrvala CA, Sherr D, Lipman RD. Diabetes selfmanagement education for adults with type 2 diabetes mellitus: A systematic review of the effect on glycemic control. Patient Educ Couns 2016; 99(6): 926-943.

8. Feingold KR. Oral and Injectable (Non-Insulin) Pharmacological Agents for Type 2 Diabetes. editors. Endotext [Internet]. South Dartmouth (MA): MDText.com, Inc.; 2020.

9. Meece J. The Role of the Pharmacist in Managing Type 2 Diabetes with Glucagon-Like Peptide-1 Receptor Agonists as Add-On Therapy. Adv Ther 2017; 34(3): 638-657.
10. Pawaskar M, Bilir SP, Kowal S, Gonzalez C, Rajpathak $S$, Davies G. Cost-effectiveness of DPP-4 inhibitor and SGLT2 inhibitor combination therapy for type 2 diabetes. Am J Manag Care 2019; 25(5): 231-238.

11. Charokopou M, McEwan P, Lister S, Callan L, Bergenheim K, Tolley K, Postema R, Townsend R, Roudaut $M$. Cost-effectiveness of dapagliflozin versus DPP-4 inhibitors as an add-on to Metformin in the Treatment of Type 2 Diabetes Mellitus from a UK Healthcare System Perspective. BMC Health Serv Res 2015; 15: 496-504.

12. Garry EM, Schneeweiss S, Eapen S, Petruski-Ivleva N, Cheever E, Murk W, Rajan A, Rassen JA, Gambino D, Jang $H$ et al. Actionable Real-World Evidence to Improve Health Outcomes and Reduce Medical Spending Among Risk-Stratified Patients with Diabetes. J Manag Care Spec Pharm 2019; 25(12): 1442-1452.

13. World Medical Association. Declaration of Helsinki: Ethical Principles for Medical Research Involving Human Subjects. JAMA. 2013; 310 (20): 2191-2194.

14. Onoviran OF, Li D, Toombs Smith S, Raji MA. Effects of glucagon-like peptide 1 receptor agonists on comorbidities in older patients with diabetes mellitus. Ther Adv Chronic Dis 2019; 10: 204-209.

15. Moghissi ES. Treating patients with diabetes of long duration: GLP-1 receptor agonists and insulin in combination. J Am Osteopath Assoc 2014; 114(5 Suppl 2): $S 22-S 29$.

16. Sun F, Yu K, Yang Z, Wu S, Zhang Y, Shi L, Ji L, Zhan S. Impact of GLP-1 receptor agonists on major gastrointestinal disorders for type 2 diabetes mellitus: a mixed treatment comparison meta-analysis. Exp Diabetes Res 2012; 2012: 230-244.

17. Horowitz M, Aroda VR, Han J, Hardy E, Rayner CK. Upper and/or lower gastrointestinal adverse events with glucagon-like peptide-1 receptor agonists: Incidence and consequences. Diabetes Obes Metab 2017; 19(5): 672-681.

18. Huthmacher JA, Meier JJ, Nauck MA. Efficacy and Safety of Short- and Long-Acting Glucagon-Like Peptide 1 Receptor Agonists on a Background of Basal Insulin in Type 2 Diabetes: A Meta-analysis. Diabetes Care 2020; 43(9): 2303-2312.

19. Kim GS, Park JH, Won JC. The Role of Glucagon-Like Peptide 1 Receptor Agonists and Sodium-Glucose Cotransporter 2 Inhibitors in Reducing Cardiovascular Events in Patients with Type 2 Diabetes. Endocrinol Metab (Seoul) 2019; 34(2): 106-116.

20. Prasad-Reddy $L$, Isaacs $D$. A clinical review of GLP-1 receptor agonists: efficacy and safety in diabetes and beyond. Drugs Context 2015; 4: 212-223.

21. Tran KL, Park YI, Pandya S, Muliyil NJ, Jensen $B D$, Huynh K, Nguyen QT. Overview of Glucagon-Like Peptide-1 Receptor Agonists for the Treatment of Patients with Type 2 Diabetes. Am Health Drug Benefits 2017; 10(4): 178-188. 